\title{
Transition Toward Participatory Democracy Through Panchayti Raj Institutions: A Paradox of Gender Equality in Himachal Pradesh
}

\author{
Prem R. Bhardwaj ${ }^{1}$ Veena Devi ${ }^{2}$, \\ ${ }^{l}$ Associate Professor, Department of Political Science, Dr. YSP Govt. PG College, Nahan, Himachal Pradesh. \\ ${ }^{2}$ Research Scholar, Department of Political Science, HNBGU (A Central University), Sri Nagar Uttrakhand.
}

\begin{abstract}
The issue of good governance though has always remained in the forefront in journey of modernisation, at least at the theoretical level, yet the unequal distribution of resources and consequently, elimination of the people living in the peripheral regions, very often create violent and bizarre conditions having disastrous implications for poor and weaker sections of the society of which the women become the first victim. In any society, no matter how developed it is, the main targets of these violent changes are women, children and the aged, particularly those belonging to lower sections of society, simply because they constitute a politically marginalized community in the so-called modern democratic age. It is under this reality that the present paper has been developed with the prime objective to explore the various dimensions of socio-political transformations in the lives of the women in Himachal Pradesh. The paper is an attempt to address the issues which hinder the path of transition of rural society towards participatory democracy through realistic and meaningful inclusion of women in political decision making. The paper argues that the poverty and illiteracy prevalent in rural areas of the state have in fact distorted the process of democratization of rural society.
\end{abstract}

Keywords: De-cultured, Deity System, Hegemonic Masculinity, Panchayti Raj Institutions, Subordination, MNREGA

\section{INTRODUCTION}

The virtues of democracy, i.e., liberty, equality and justice, have changed the dimensions of modern human civilization in a dramatic manner. The series of transformations leading to modernisation of mankind is motivated and guided by the scientific and technological revolution. It is indisputably true that the pursuit of human knowledge has always been to create an egalitarian society, but unfortunately, even at this stage of modernisation and development the people at the helm of socio-political affairs have been using knowledge and technology to consolidate their power and position The control of resources of human development by handful of people in the countries like India has been defeating the goals of democracy, and at this point of time, in the pseudo-democratic environment, the human societies appear more fragmented than any time in the human history. The issue of good governance though has always remained in the forefront in journey of modernisation, at least at the theoretical level, yet the unequal distribution of resources and consequently, elimination of the people living in the peripheral regions, very often create violent and bizarre conditions having disastrous implications for poor and weaker sections of the society of which the women become the first victim. In fact the claims of modernisation have been nullified by the gross violations of human rights of the people belonging to marginalised sections of the people; by economic injustice that too in the age of democracy; and by perpetually increasing inequalities among the different sections of the society, which have thrown almost the entire human society to the turbulent stage of instability, breakdown and disaster. In most of the cases the people who want to keep the hold on resources for their petty interests inflict these crises artificially. In any society, no matter how developed it is, the main targets of these violent changes are women, children and the aged, particularly those belonging to lower sections of society, simply because they constitute a politically marginalized community in the so-called modern democratic age.

There is no doubt that the humanity has progressed tremendously in last hundred years or so, particularly on account of knowledge and science and technology, leading to general prosperity and abundance of resources of sustenance. But, still the large parts of human population are deprived of the basic life values all across the globe. Exploitation, subjugation and deprivation of the fellow-beings by their counter parts are as old as the process of modernization, development and advancement, rather it can be stated evidently that the marginalization of people has increased with the pace of progress and development and the women are the real victim of such socio-economic and political disorders.

Since the women constitute almost half of the human population and are socially the integral part of human development, their whole involvement in decision making not only within the social institutions but also in the political institutions, determines the path of transition of human civilization towards egalitarian human society. It is important to say that no human society can progress without including women in all walks of life. 
If we see the role of women from ancient time to modern era, it is evident that the societies which had neglected the role of women from the process of political decision making have suffered allot particularly in term of human development. The role of women in uplifting the standards of human society at social level is of paramount importance.

\section{METHODOLOGICAL FORMULATIONS}

This is a sincere attempt to investigate the issues related to the women participation in political decision making in state of Himachal Pradesh (hereafter HP) in India. The paper is primarily based upon broader research project undertaken for Ph.D. degree conducted in districts Sirmour and Solan of HP. Methodology adopted in the course of study is based upon survey research design technique in comparative perspective which implies that the informations were gathered from the field through structured questionnaires. It is pertinent to mention here that there is a reasonable homogeneity in terms of factors determining the status of women in socio-economic settings of society in Himachal Pradesh. There is almost similar kind of correlation among different variables that determine the capability of women in political decision making in HP. Thus, the present paper is based on deductive technique which implies that the analytical formulation of data for sampled universe can fairly be applied for broader generalization of trends related to transition toward democracy through Panchayati Raj Institutions (hereafter PRIs) visible in entire state. At this stage it is only an attempt to enrich the level of knowledge and information about the various dimensions of human development in state of HP, which is culturally distinct but isolated from other states of India.

There are certain questions which prompt researchers to conduct study on gender based aspects of political transition in Himachal Pradesh. For instance, how far the economic status of women in traditional social settings is affecting their involvement in political decision making? How far existing political institutions in state are capable in sensitizing the women for engaging themselves with the various programme initiated by the government for their upliftment? How far the goals of political transformation through PRIs, particularly in terms of women empowerment, have been successful in HP? How the process of democratization through PRIs is accommodative and sensitive to the inclusion of women in political institutions? How to understand the paradox of gender equality in rural areas of Himachal Pradesh through Panchayat Institutions? How the objective of gender equality is being realized through the inclusion of women in local self government? Besides these questions there are many related issues that fall in the domain of the current political discourses and are being dealt in this research paper.

\section{HIMACHAL PRADESH AT GLANCE}

The state of Himachal Pradesh is one the units of Indian federal system situated in North-West part of the country. The word "Himachal" derives from two Hindi words: "Him" and "Anchal" meaning snow and lap, respectively. Himachal or the land of snow as it is called, lies in the lap of Himalayas. The Himalayas is not a single continuous chain of mountains but a series of parallel ranges from Kashmir to eastern end of Assam. The Himalayas form a shield of great importance right across the northern façade of India from Jammu and Kashmir in the West to Arunachal Pradesh in the East. But it is only one state, Himachal Pradesh, which drive its name from the Himalayas.

The state has its capital at Shimla which is historically very popular place and which is not only known at National level but also at world level. Shimla was the Summer Capital of the British India. At present Shimla is Capital of Himachal Pradesh but for few days Dharmshala is winter capital of Himachal Pradesh. Himachal Pradesh is almost entirely a mountainous region with attitudes ranging from 350 meters to 5,975 meters above the sea level. It has a deeply dissected topography complex geological structure and a rich temperate flora in the sub tropical latitudes. The Himachal Pradesh region is situated $33^{\circ} 22^{\prime} 40^{\prime \prime}-30^{\circ} 2^{\prime} 40^{\prime \prime}$, North and $75^{\circ} 47^{\prime} 55^{\prime \prime}-$ $79^{\circ} 04^{\prime} 22^{\prime \prime}$ East and has an area of 55,673 sq. kilo meters. From the administrative point of view, the state has been divided into twelve districts and is surrounded by Jammu and Kashmir in the north, Punjab and Haryana in the west, Uttra Khand in the South and shares international border with Tibet in North East.

\section{MAPPING STATE OF WOMEN EMPOWERMENT IN HIMACHAL PRADESH}

Women Empowerment is conceived as a process by which women can overcome many of the hurdles that they face, such as lower education, poor working status, inadequate employment opportunities, poor health care, social insecurity, and poor political participation by virtue of their gender identity. Thus, the empowerment of women veritably implies eradication of "subordination" or "discrimination" and injustices done to them in male dominated society. Formulating a National Policy for Empowerment of Women and setting up a National Resource Centre for Women are main efforts undertaken by the union government in the interest of women. The government of Himachal Pradesh has also undertaken many gender empowerment initiatives to upgrade the status of women on same analogy. There are various dimensions of women empowerment such as psychological, social, economic, political and legal. Among all these dimensions the economic aspect 
constitutes probably the most important one simply because their involvement in political decision making is determined by their placement in economic settings. The economic empowerment of women means their participation in economically productive activities; their access to savings and credits and their control over income and other productive assets such as land, business and industries. Alike rest of India, despite legislation on equal pay for equal work, women continue to be paid considerably less than men in Himachal Pradesh also, even when the occupational category and actual hours of employment are virtually same. It is encouraging that of total women employed in organized sectors in Himachal, 94.95 percent are in the public sector but this is mainly in lower-cadre jobs. At this point of time let us resolve to forget the ancient Indian scriptures having the instances of women scholars and rulers widely accepted and legitimized by the greater part of population, especially by men. This is probably where the Indian society has de-cultured as men have not only patronized their status and position but have also rejected the capabilities of women out-rightly in almost in every sphere of economy and politics. It appears that this all has emerged by virtue of the decisive control of men over the modern political institutions in the so-called democratic age. It is absolutely paradoxical that the spirit of democracy is being (mis)used by the dominant ruling elites to exclude the women from the areas of value generation and control mechanism. There are some region specific socio-economic conditions that affect the success of the initiatives undertaken by various governmental agency and NGOs for the women empowerment through various programmes. In fact, this journey towards the participatory democracy in HP is determined by the factors that affect the positioning of women in dynamic rural social settings. It is generally assumed that the human rights of women in any society are overshadowed by masculinity, which is practised very often on the ideological construct that 'women constitute the weaker partner in all social setting'. Alike a typical patriarchical society, the social set up in HP in general is structured on hegemonic masculinity in which ideals are constructed and realised by a small number of men, who control power and wealth. Such hegemonic norms are made valid for bulk of the population which remains relatively powerless, even while they are complicit in sustaining the hegemonic masculinity at a broader level by desiring to imitate it. Thus, dominant masculinity in the region is placed in ideological framework unnaturally and is shaped in a manner to suit the patriarchy irrespective of caste, class and race. It is needless to argue that the standards of human rights are determined precisely by the availability of socio-political and economic indicators such as healthcare facilities, educational opportunities, political participation and economic avenues. Besides these, the cultural origin and religious beliefs deeply embedded in social structures, determine the course of human rights in any society. Contrary to neighbouring states, the rural society of HP is having strong traditional linkages which determine the status of women in almost entire state.

\section{SOCIO-ECONOMIC DIMENSION OF GENDER EQUALITY IN HP}

Right at the outset it is pertinent to provide a synaptic view of existing socio-economic conditions in Himachal. The women constitute the back bone of rural economy of Himachal Pradesh. Probably the most perplexing area, with which the numbers of contradictions emerge, pertains to the economic conditions. Ironically, the women are dis-proportionality overburdened in the economic settings of the state. In rural areas women have been working right from early morning to till last in late night. In fact, in a typical Himachali family the women are the first to leave the bed in morning and last to go to bed in night. Women are first victim of any economic hardships which the family faces. The first visible impact of poverty is malnutrition of which women are prime victim and unemployment of men can be identified on the faces of women easily. The conditions of women in urban areas are not much better as compared to their counterparts in rural areas. Women working in organized or semi-organized sectors in the urban centers are doubly burdened i.e., they have been working outside only after completing the daily domestic work. The involvement of men in domestic activities is restricted to only the area which involves heavy labour such as ploughing the agricultural fields, carrying heavy material to field or from field to home, etc. It is interesting to state that the division of labour on the basis of gender is discriminatory in nature. It is more so in areas having less women literacy rate and higher poverty. Even various programmes adopted by the government for upliftment of women have not been very successful in weakening the clutches of patriarchy and creating the respectable space for women in society. However, the picture in rural areas has changed dramatically after the implementation of Mahatma Gandhi National Rural Employment Guarantee Act (hereafter MNREGA) in gender perspective. Now the women in rural areas are insisting more upon their greater engagement in the outdoor activities through MNREGA, which is seen as an opportunity by them. The biggest contribution of this change is witnessed in the form of economic empowerment of women as they are able to get hard cash directly of which they were denied earlier. Since there is a close connection between the MNREGA \& PRI's as later is the implementing agency, there is direct impact of political economy on the economic empowerment of women. However, despite women's involvement in MNREGA they are hardly spared from the area of their domestic involvement that means the cost of economic independence of women in rural areas, especially in relatively backward areas, is too costly for them. Here it is important to mention that MNREGA has not enhanced technical capabilities of women. Engaging women in 
rural economy by building their capacities to perform well will surely transform their socio-economic status. In real sense MNREGA has been providing sustenance to women without their actual economic empowerment.

The impact of better economic conditions and educational opportunities is already visible in participation of women representatives in the trainings being organized by the administrative department of the government. A less number of women representatives participate in such trainings workshops in areas stricken with poverty and backwardness as compared to areas having better literacy rate and economic opportunities. At the same time it is evident that in such areas a very few number of women representatives do enquire about the various plans of development that are being adopted by the government from time to time. The role being played by the women in public institutions, mainly in PRIs, in capacity of representatives, also reveals almost similar story. The women representatives of relatively backward regions are found far behind in spending the budget allotted by the government for carrying the developmental activities appropriately as compared to women representatives coming from developed areas. Thus, clearly the performance of women representatives in political institutions is greatly influenced by the level of their education and their economic conditions.

It is pertinent to mention here that the economic empowerment of women in developed areas can clearly be attributed to large number of factors such as higher literacy rate, occupational diversification mainly in the service sector, modernization of economy with incorporation of tourism, industry, telecommunication, new technologies in the agricultural sector and adoption of commercial crops, development of horticulture, etc. All these factors have led to dramatic changes at social level. It is clear that as consequence of better economic opportunity and higher educational qualification, significant changes in the political behaviour of women have been witnessed in all sections of society in state. In fact all these factors have increased the occupational mobility of women and in general gender discrimination is less prominent in such areas. The way the women are using the new opportunities it can be stated that the ever increasing expansion of market in rural areas will surely facilitate the process of rural transformation mainly after incorporation of women within the ambit of market. It is simply because the better economic conditions increase the capacities of women to think independently and to involve meaningfully in the public discourse. So, the greater economic opportunities should be provided for women so that they could become self-reliant and could be enabled to come out of the dominance of the male members of their family, particularly in backward regions where women are the real victim of poverty. Though, MNREGA has played instrumental role in empowering the women economically at rural level in such areas yet they still lack the sustainable source capable to enhance their economic capacities.

\section{MAPPING THE ROLE PRIS IN ENSURING HUMAN RIGHTS OF WOMEN IN HP}

It is needless to argue that the standards of human rights are determined precisely by the availability of socio-political and economic indicators such as healthcare facilities, educational opportunities, political participation and economic avenues. Besides these, the cultural origin and religious beliefs deeply embedded in social structures, determine the course of human rights in any society. The conditions of general indicators of human rights of women of Himachal Pradesh clearly hint on prevalence of discrimination against them. The following generalisations made on the basis of the empirical observation of factors project a general picture of human rights of women living in Himachal Pradesh. The hegemonic masculinity in the almost entire state is deep rooted in the cultural ethos and traditional linkages on which the society is structured. The mindset of women is tuned in such a manner that they have been accepting the dominance of their male partners as the cultural component of their lives. In fact they think it as 'god given'. Alike any other patriarchical society, the women in Himachal Pradesh are granted an inferior status as compared to men. It is clearly visible that the discrimination against women starts from within family particularly, in the form of poor quality of food and blockage of educational opportunities for girl child. It is clear that the conditions of women are miserably poor as they are being exploited doubly, i.e., within families by their male partners and in the society where they are forced to submit before the forces of exploitation. This is more so in case of women belonging to backward communities who are human beings but have virtually no rights. Even the rural political institutions (PRIs) have not been successful in transforming the ground realities that are largely responsible for gender discrimination.

The society in Himachal Pradesh is deeply traditional and the religious belief system like the superstition, the local 'Deity System', Ghost and 'Zadu-Tona', affect the society as a whole in general and women in particular. The women are made to belief that they are subservient to the males and it is their god driven duty to serve them. The positioning of women in cultural settings of the society in almost entire state reflects that they are the first victim of such orthodox practices.

Although, the women have been given reservation in PRIs, yet their status in general has remained by and large unchanged mainly because of two reasons - firstly, the women who have secured their seats within these institutions come from upper middle class families in all categories i.e., the families in which the women have been enjoying relatively better quality of life, secondly, because of prevalent male superiority women are 
being directed and sometimes forced to act in political institutions in accordance with the 'will' of their male partners. Thus, even the political positions and also the political rights are not being enjoyed independently by women rather in majority of cases they represent their male partners in PRIs, not the women community.

Women belonging to lower sections of society get inadequate supply of quality nutrition because of poverty and underdevelopment and the girls became the first victim of such discrimination right within the family. Consequently, a large number of women in the region suffer from serious nutritional diseases such as anaemia, asthma and tuberculosis. In the absence of proper healthcare centres in rural areas conditions of women suffering from such diseases get very often deteriorated. In some areas, such as rural areas of Sirmour district, the conditions of abject poverty have forced the women to unethical practices of human trafficking.

The poor state of human rights of women in Himachal Pradesh is mainly because of their confinement in homes. The day of a woman starts with the kitchen works early in the morning and ends in the kitchen in late nights and for whole day they remain tirelessly busy. Besides domestic affairs, they manage fodder and grazing of animals, work in land holdings and look after their children. Not only that, the outdoor field works are assigned to women disproportionately as males are engaged in unproductive activities such as idle wandering in semi-urbanised markets. Very rarely females are accompanied by their male partners in the fieldworks. In this manner women have virtually no time to think about the quality of life or about their rights. It was very rightly stated by a senior citizen (retired teacher, a villager in Sirmour district) of the area during the survey that, 'women constitute backbone of the regional economy and if they would come out of traditional economic set up than the males would starve'.

Alike in any patriarchical society the violation of human rights of women in HP starts from the beginning i.e., right after birth. The environment within homes is clearly based upon discriminatory practices in terms of sex. Right to education to girl child is the secondary priority at the family level. Similarly, the women do not enjoy the same political rights as men do in most of rural areas of HP simply because they do not get minimum space in public discourses. Right to property, right to protection of health, right to equal opportunity to work, right to equal wages and right to live with dignity are not granted with fare degree of equality with men. So much so the placement of women in local 'deity system' is clearly contrary to the principles of universal equality. Ironically, the practices related to deity system are clearly discriminatory against women. The women become the first target of the so called 'devil forces', particularly in rural areas where all forms of superstitions are practised. It implies that the semi-tribal society of the state does not provide respectable space for women in cultural settings.

\section{CONCLUSIONS}

Thus, the common women in almost entire state have been reduced to tool of economy in existing socio-economic and political conditions but without acknowledging their role in building the socio-cultural foundations. The present status of the indicators of human rights of women in the region indicates a very grim situation of their acute exploitation. The instances of selling of young girls by their parents for a meagre amount in the age of so-called modern civilisation tell an inhumane story of mankind. Without a constructive interventionist approach, particularly at the part of government and NGOs, it is quite difficult to standardise the human rights of the women of the region. The women need to come out from the age-old social dogmas deep rooted in the society. In such a highly discriminatory social order the power cannot come as gift. Some agencies have to work collectively in this direction so that the attitude of both men and women could be changed in order to provide a sufficient space for women in the society. In order to bring qualitative changes in the life values of the women, the governmental agencies have to work for their interests particularly through health centres, educational institutions and economic policies so that their exploitation could be ended to great extent which would ultimately increase the rights of the women of the region. Mere transfer of funds would make no change without opting for basic structural changes in the society.

It is clear the ultimate goal of inclusive development cannot be achieved without adopting the effective strategies for including the excluded sections of society especially women, in democratic processes. It can clearly be established from the trends prevailing at grassroots level that the impact of poverty and marginalization are more severe for women as compared to men. Poverty and illiteracy prevalent in rural areas of the state have in fact distorted the process of democratization of rural society. It is true that large numbers of women have entered into active politics after successful implementation of $73^{\text {rd }}$ and $74^{\text {th }}$ constitutional amendments, but their real empowerment is still a distant dream simply because majority of them represent the will of their male partners instead of their own will. 